\title{
O PROBLEMA DA SUBJETIVIDADE NA CONFIGURAÇÃO DO ABUSO DO DIREITO DE MINORIA.
}

\author{
Ilton Garcia Costa ${ }^{1}$ \\ Clayton Reis ${ }^{2}$ \\ Gustavo Afonso Martins ${ }^{3}$
}

\section{Resumo}

Objetivo - Analisar a construção jurisprudencial sobre a configuração do abuso de minoria, bem como perquirir quanto ao(s) problema(s) da subjetividade no ato de decidir no que tange a configuração do abuso do direito de minoria nas relações societárias.

Metodologia - A metodologia utilizada é por meio de pesquisa bibliográfica e documental, para tanto, vale-se da análise da doutrina e análise de jurisprudência.

Resultados - O artigo destacou que a configuração do abuso de minoria é um problema oriundo da subjetividade decorrente das teorias que tentam classificá-lo, tanto quanto subjetividade aparente, que aqui se apresenta como sendo aquela que afasta qualquer dúvida desde que, sejam observados precedentes e os parâmetros por ele fixados para a constatação do abuso de minorias.

Contribuições - A principal contribuição do artigo é fazer uma pesquisa quanto a subjetividade decorrente e aparente sobre o abuso de minoria, para distinguir, vale-se da técnica de observância aos precedentes a fim de encontrar um ponto comum entre alguns julgados que seja incontroverso o abuso.

Palavras-chaves - Direito; subjetividade; abuso de minorias; precedentes.

\section{Introdução}

\footnotetext{
${ }^{1}$ Possui doutorado em Direito pela PUC-SP Pontifícia Universidade Católica de São Paulo, mestrado em Direito pela PUC-SP, mestrado em Administração pelo Centro Universitário Ibero Americano UNIBERO. Graduação em Direito pela Universidade Paulista UNIP. Graduação em Matemática pela Universidade Guarulhos UNG. Especialização em Administração Financeira pela Alvares Penteado, Especialização em Mercados Futuros pela BMF - USP, Especialização em Formação Profissional na Alemanha.

${ }^{2}$ Doutor em Direito pela Universidade Federal do Paraná. Mestre em Direito pela Universidade Federal do Paraná. Bacharel em Direito pela Faculdade de Direito de Curitiba. Magistrado em Segundo Grau, aposentado, do TJPR. Professor na Escola da Magistratura do Paraná e pertence ao Corpo Docente Permanente do Programa de Mestrado em Direito Empresarial e Cidadania do UNICURITIBA. Realizou estágio Pós-doutoral na Faculdade de Direito da Universidade de Lisboa-Portugal.

3 Doutorando, mestre em Direito Empresarial e Cidadania pelo Centro Universitário Curitiba UNICURITIBA. E-mail: gustavoamartins.cwb@gmail.com
} 
$\mathrm{O}$ artigo analisa o tema: abuso de minorias nas relações societárias, seja pelo prisma da jurisprudência, assim como da doutrina. O que possibilita perceber um fenômeno que não raramente dificulta a sua configuração/constatação na medida em que se depara com a subjetividade das teorias e consequentemente, no ato decisório.

Assim, o artigo perpassa pelas principais teorias sobre o abuso de minoria, destacadas por Marcelo Von Adamek, posteriormente, por julgados, desde tribunais de justiça, até a decisões do Superior Tribunal de Justiça a fim de revelar o descompasso entre a teoria e sua aplicação.

Diante do exposto, o artigo propõe como critério para afastar a subjetividade na configuração do abuso de minorias, e fixar parâmetro, a análise dos precedentes sobre a matéria. Para tanto, se fará uma distinção entre subjetividade decorrente (das teorias), e subjetividade aparente. Em outras palavras, a técnica de observância e respeito aos precedentes, pode parametrizar - ser um critério - para definir condutas abusivas das minorias, de modo a tornar aquela subjetividade em meramente aparente.

Nesse sentido, o artigo está dividido em três partes, a primeira ater-se-á à doutrina, fundamentalmente com base na obra de Marcelo Von Adamek, "Abuso de minoria em direito societário - abuso das posições subjetivas minoritárias". A segunda etapa traz a constatação quanto a má compreensão do conceito de minoria, analisando, p.ex. o Recurso Especial no 1.337.989 SP/2011/0269578-5, de relatoria do Min. Luis Felipe Salomão. Por terceiro, apresenta os precedentes como critério e/ou técnica para se configurar o abuso.

\section{ABUSO DE MINORIA E A DOUTRINA}

Como já delimitado na introdução, o referencial teórico desse capítulo é preponderantemente o livro de Marcelo Von Adamek, "Abuso de minorias em direito societário - abuso das posições subjetivas minoritárias". Assim, os demais referenciais utilizados servem para dar suporte os pressupostos apresentados por este autor, vez que a pretensão do artigo não é em especial tratar das teorias que abordam o tema, mas sim do(s) problema(s) da configuração do abuso de minorias diante do caso concreto.

\subsection{ABUSO DE MINORIA EM DIREITO SOCIETÁRIO}


Ao tratar do tema "minoria" em direito societário é lembrar também da "maioria", são indissociáveis na medida em que se está em jogo o controle, poder e abuso. Este último elemento podendo ser exercido pela minoria ou pela maioria. É o que se extrai das palavras de Adamek (2010, p. 16) "grupos minoritários, tanto quanto os majoritários, podem ser responsáveis por graves abusos e desmandos no âmbito da coletividade em que se inserem".

A construção que se faz dos abusos de minorias em casos extra societários, p.ex. aqueles ocorridos no cotidiano, evidencia que normalmente são praticados por grupos sem o elemento; poder de controle, portanto, possuindo apenas o elemento: abuso, nesse extrapolam sem a preocupação prática de seus atos, isso é exemplificado por Adamek (2010, p. 16) com as manifestações de grevistas e congressistas, que mesmo ao possuir um legítimo direito de se opor, se valem de forma abusiva e corrosiva à finalidade daquilo que subjetivamente e hipoteticamente defendem, vez que nem sempre a oposição consegue mensurar qual é a consequência de sua atitude, ou seja, é um obstáculo oposicionista por mera birra em não se ver prosperar propostas diversas das deles (grupo minoritário).

Para que não seja interpretado equivocadamente, as duas posições: maioria e minoria, são "necessária, para o adequado funcionamento da organização, como o poder de controle, que aquela idealmente busca conter, refrear e adequar aos propósitos legalmente estabelecidos". (ADAMEK 2010, p. 18).

Não é por outra razão que Adamek (2010, p. 17) destaca que:

Em todas essas situações, o que singulariza o abuso da minoria é o fato de ela não ser um grupo de controle minoritário, não se colocar na posição fática de deter minoritariamente o poder de mando, agir, autenticamente, como minoria em face da maioria dominante dentro da coletividade.

Os exemplos de abuso de minoria na sociedade civil se estendem também nas relações societárias, "não é e nem poderia ser, desconhecida no seio das demais organizações privadas coletivas, pessoas jurídicas ou coletivas despersonalizadas”, (ADAMEK, 2010, p. 17), depreende-se, portanto, ser uma característica daqueles que detém o poder em abusar dele (ADAMEK, 2010, p. 18), e aqueles não o possuem, de se opor o que nesta ocasião pode acarretar abuso de minoria em exercer o direito subjetivo. Assim, Adamek (2010, p. 17), enfatiza que "se trata de realidade característica e indissociável do próprio fenômeno associativo e dos conflitos que nele se encerram". 
É dentro do cenário societário que o artigo repousa sua atenção a fim de apresentar as teorias existentes quanto ao abuso de minoria, e diante da construção teórica, poder-se-á analisar seu reflexo na jurisprudência, o que já permite antecipar que se faz necessário fixar algum critério para afastar a subjetividade do julgador ao apreciar a problemática do abuso de minoria e a sua constatação se se trata de abuso ou não.

Nessa perspectiva, é que também é possível antecipar o que se entende por subjetividade decorrente e aparente no que tange o abuso de minoria em direito societário. E o que as teorias visaram responder foi: Quando se caracteriza o abuso da minoria?

Adamek, (2010, p. 18), responde:

\begin{abstract}
Quando a minoria, à qual são assegurados direitos e prerrogativas próprios e insupríveis, utiliza os poderes que daí derivam para a satisfação de fins e interesses diversos daqueles em torno dos quais foram estabelecidos, ou com menosprezo dos interesses igualmente merecedores de tutela dos demais, temse a situação de abuso da minoria, "a tirania dos fracos".
\end{abstract}

Depreende-se que o abuso é a medida que excede o direito subjetivo da parte de fazer ou deixar de fazer, aquilo que é necessário para atingir a finalidade da sociedade empresarial que via de regra é definida em seu contrato social. Mesmo diante do conceito acima, e daquilo que se pode deduzir dele, por si só não basta para afastar a subjetividade do julgador quando se deparar com tal situação no caso concreto, vez que ele (o julgador) ora poderá se valer da "finalidade", "essencialidade" e até mesmo "conflito de interesse", essa constatação decorre da análise do abuso de minoria em Direito comparado, os quais serão analisados na sequência.

\title{
2.2 TEORIAS A RESPEITO DO ABUSO DE MINORIA
}

É inequívoca a construção doutrinária quanto ao conceito apresentado por Waldirio Bulgarelli (1998, p. 33) quando menciona que "a expressão minoria não se refere a uma noção meramente quantitativa, mas uma relação qualitativa de poder, que não corresponde ao número de pessoas, nem de ações, necessariamente”.

Com a definição acima, torna-se possível a compreensão de Adamek (2010, p. 44) ao fixar que minoria é o não-controlador, pouco importando a proporção e a espécie de sua participação societária. É uma situação jurídica subjetiva de sócio diante da sociedade e dos demais membros. (2010, p. 44). Portanto, o elemento: poder de controle é a configuração de maioria, em sentido contrário, encontra-se a minoria, que no exercício 
de seu legítimo direito pode se opor, e é justamente no exercício deste que reside a dificuldade de identificar quando é ou não abusivo a oposição.

Diante do cenário de dificuldade, não conceitual, mas de configuração de abuso, surgem teorias com o intuito de apontar hipóteses teóricas daquilo que pode representar o abuso de minoria em relações societárias. O que se pode verificar é que se trata de um abuso no "exercício pelo sócio de cada uma e todas as posições jurídicas subjetivas ativas inerente à sua situação jurídica, à sua posição contratual na complexa relação jurídica societária”. (ADAMEK, 2010, p. 52).

Parametrizado a abusividade da conduta entre sócios, independentemente de sua posição jurídica, a teoria sobre o abuso de minoria se verifica inicialmente através do direito comparado, visando sua sistematização, o que já se pode antecipar, recair no problema do subjetivismo.

Adamek destaca como sendo a França e Alemanha os principais países a discutir a temática do abuso de minoria em direito societário, seja pela doutrina, bem como pela jurisprudência que diante do caso concreto, visam a adequação e sistematização do instituto.

De modo sucinto, o "ordenamento societário francês, ainda hoje, não conhece norma de caráter geral voltada a disciplinar, em via abstrata, e sancionar os conflitos de interesses no âmbito dos órgãos colegiais”. (ADAMEK, 2010, p. 55). O que propõe o Código Comercial francês é apresentar casos hipotéticos de conflito, contudo, não enfrenta sistematicamente o "contraste entre os interesses da sociedade (...) e os interesses extrassociais do sócio ou do administrador" (ADAMEK, 2010, p. 55) a fim de parametrizar o que configuraria uma conduta abusiva passível de repreensão e, consequentemente invalidação daqueles atos conflitantes.

Como registra Adamek (2010, p.55-56):

$\mathrm{Na}$ ausência de texto legal, segundo registra Paul Le Cannu, uma jurisprudência pragmática edificou-se em torno do instituto do abuso do direito, para estigmatizar os comportamentos faltosos dos sócios que atuam em contemplação de objetivos egoísticos e dissonantes daqueles que os levaram a associar-se, de tal modo que, assim positivada a ilegalidade da conduta abusiva do sócio, se possa então obter a invalidação da deliberação social inquinada. É que, quanto a isso, a invalidade das deliberações societárias no direito francês apenas é reconhecida nas situações expressamente indicadas, dentre as quais não se encontra a decisão conflitante com o interesse social; foi preciso assim enquadrar os conflitos de interesses e, em especial, os abusos de sócios entre "I" une des causes de nullité des contrats en général (CC fr., art. 1844-10, al. 3; e CCom fr., art. L. 235-I). (g.n.) 
É perceptível, portanto, que da leitura do trecho acima, a jurisprudência francesa se edifica em pressupostos subjetivos, que, salvo melhor entendimento, exige a análise de atos "faltosos" dos sócios que atual com "objetivos egoísticos" e dissonantes daqueles que os levaram a associar-se. Questiona-se: o que configuraria um objetivo egoístico? É ama pergunta retórica apenas para mostrar o quão subjetiva pode ser a resposta e sua tipificação.

Diante da dificuldade que a subjetividade expõe o tema, um passo inicial para se chegar a compreensão francesa de abuso de minoria foi contrapô-la aos elementos caracterizadores daquilo que se compreende por abuso de maioria. Adamek, (2010, p. 56), destaca a posição da Corde de Cassação francesa:

\footnotetext{
Que até hoje se mantem fiel à formulação inicial, o abuso de maioria pressupõe a conjugação de dois elementos (i) a tomada de decisão contrária ao interesse geral da sociedade e (ii) no único desejo de favorecer os membros da maioria em detrimento dos membros da minoria (ruptura da igualdade entre os sócios)".
}

Os dois elementos que a Corte de Cassação francesa exigem, isoladamente poderiam até se apresentarem como critério para configurar o abuso de maioria, o problema é que ao se exigir a presença de ambos, decorrente da dinâmica dos mercados, algumas operações abusivas ficariam impunes. Uma vez configurado o abuso de maioria, via de regra, a consequência prática é a invalidade do voto, e outros atos que desta invalidade decorra.

O que vale deixar de destaque, em uma leitura inicial é que constatada a tomada de decisão contrária ao interesse geral da sociedade, já desperta a atenção para um possível exercício de abuso de maioria em detrimento à minoria.

Em relação à configuração do abuso de minoria, segundo Adamek (2010, p. 58):

Parece descender da mesma lógica. Afinal, segundo observa Paul Le Cannu,
se o interesse da sociedade pode se impor à maioria, ele deve assim também
guiar os sócios minoritários no exercício de suas prerrogativas. (...) em última
análise, seja para os majoritários seja para os minoritários, a vida em sociedade
requer não somente o desejo inicial de associar-se, mas a diuturna colocação
em prática desta intenção: "o espírito de comunidade não pode se limitar à fase
de criação da sociedade.

Depreende-se que independentemente das posições jurídicas subjetivas que cada grupo se enquadre, cada qual tem um desafio comum, o de manter-se naquele desejo 
inicial de associar-se, assim como o exercício diário de assim permanecer a fim de atingir a finalidade que motivou à associar-se. Portanto, a causa comum que ambas posições descendem é o conflito de interesses, assim como "os seus elementos constitutivos (...) também ser idênticos: a vontade de satisfazer interesse pessoal oposto ao interesse comum dos sócios". (ADAMEK, 2010, p. 58).

Porém, mesmo que a ambas as posições jurídicas subjetivas descendam da mesma lógica, a Corte de Cassação francesa interpreta de modo distinto, aquilo que se vale para caracterizar o abuso de maioria não serve, por si só, para configurar o abuso de minoria. A resposta destacada por Adamek (2010, p. 59) foi:

\footnotetext{
Por quê? Porque, segundo destaca Dominique Schmidt, decidir se uma decisão foi tomada contrariamente ao interesse social é uma coisa; julgar que a ausência de decisão é contrária a este interesse, é outra, completamente diversa.

No primeiro caso, apreciam-se ex post os efeitos de uma decisão tomada.

No segundo, o tribunal deve não apenas analisar a situação criada pela ausência de decisão, mas, ademais, estimar ex ante que, se a decisão tivesse sido tomada, ela importaria efeitos benéficos e, mais, justificar que essa decisão não-tomada era, ela própria, apta a satisfazer dito interesse social.
}

Depreende-se que a situação de análise por parte do tribunal francês estava em conflito entre o ato de decidir e a o interesse dos sócios, o que é apontado por Adamek (2010, p. 58), "por duas razões essenciais: de início, não está habilitado a governar a sociedade"; o que permite perceber a cautela entre interesse privado - autonomia da vontade entre os sócios - e um ato alheio àquela manifestação particular. Outra razão apresentada por Adamek (2010, p. 58), baseia-se no fato de que, "além disso, o interesse social a definir seria, segundo a concepção da Corte de Cassação, distinto daquele interesse comum dos sócios".

Em síntese o que se verifica é que os maiores interessados em resolver o litígio de modo a preservar a finalidade da empresa, e o objetivo outrora que motivou a reunião dos interesses dos sócios, era, por sua vez, deles de modo que uma decisão extra partes significaria a alteração daquela finalidade inicial - precípua - que os reuniu, o que poderia, inclusive, interferir na consecução do objeto social.

Para a Corte de Cassação, tais decisões deveriam respeitar dois critérios, o que ficou definido pela jurisprudência francesa foi: (i) ofensa ao interesse comum; e (ii) ofensa ao interesse social - pelo bloqueio a operação essencial. 


\subsection{A CONSTRUÇÃO DA JURISPRUDÊNCIA A RESPEITO DO ABUSO DE MINORIA}

\subsubsection{A experiência francesa}

É a partir da análise francesa que se extrai o nascimento jurisprudencial quanto a configuração dos requisitos do abuso de minoria que surgiu em julgado da Corte de Cassação, de 15.07.1992. Em síntese, narra-se que mesmo sem o quórum de deliberação estivesse preenchido, por efeito da ausência da sócia Madame Six, que fazia oposição à operação visada pela sociedade empresária, ainda assim os demais sócios, julgando abusiva a conduta de oposição da sócia ausente, deram por aprovada a transformação da sociedade em anônima.

Por ser vencida na deliberação societária, e inconformada, a sócia ausente, que detinha um quarto do capital social, demandou em juízo a invalidação da transformação, pelo motivo de que a maioria de três quartos do capital social não havia sido observada, como de fato não foi. Ou seja, a regra do contrato social não havia sido observada adequadamente, mesmo que a oposição dela frustrasse a deliberação da maioria.

Nesse sentido, a Corte de Apelação de Paris entendeu que os demais sócios estariam tutelados juridicamente, e a demandante sem razão, o que levou a Corte a rejeitar a demanda, alegando que "Madame Six, por sua ausência sistemática impedindo a tomada de decisão, teria cometido abuso de minoria e, na visão dos juízes, os efeitos danosos para o interesse social não poderiam ser reparados senão pela rejeição da ação de invalidação da deliberação". (ADAMEK, 2010, p. 59).

Após a decisão da Corde de Apelação, Madame Six recorre à Corte de Cassação, onde obtém êxito, na medida em que fora cassada aquela decisão local, in verbis:

\footnotetext{
Considerando que, em se baseando em tais motivos, impróprios a determinar no que a atitude da Sra. Six foi contrária ao interesse geral da sociedade, em que a Sra. Six teria impedido a realização de uma operação essencial para esta, e no único desejo de favorecer seus próprios interesses em detrimento do conjunto dos outros sócios, a Corte de Apelação não deu base legal à sua decisão.
}

Desta decisão, Adamek (2010, p. 60), aponta que:

Sobressaíram do julgado duas razões para a cassação do aresto local: Em primeiro lugar, a Corte de apelação não teria bem caracterizado as condições de abuso da minoria, que supõe "uma atitude contrária ao interesse geral da sociedade, em que o sócio impeça a realização de uma operação essencial para 
aquela, e com o único desejo de favorecer os seus próprios interesses em detrimento do conjunto dos outros sócios", e, em segundo lugar, porque, mesmo se o abuso de minoria tivesse sido estabelecido, ele não seria de molde a tornar válida a decisão irregular tomada. Ou seja, neste julgado, a Corte de Cassação elaborou o conceito de abuso de minoria e, ao mesmo tempo, exprimiu a regra de que o juiz não pode reputar regular a deliberação tomada sem o quórum exigido, pelo fato de ter havido abuso da minoria. (2010, p. $59 / 60)$.

Decompondo-se o conceito de abuso de minoria aí apresentado, destacam-se dois elementos específicos: O minoritário tem por único desejo favorecer seus próprios interesses em detrimento do conjunto dos outros sócios, e sua atitude é contrária ao interesse geral da sociedade ao impedir a realização de uma operação essencial. Ocorre que ao fragmentar a decisão, surgem outros elementos caracterizadores do abuso de minoria, demasiadamente subjetivos, p.ex.: próprios interesses, interesse geral e operação essencial.

\footnotetext{
No primeiro elemento, pode-se identificar a exigência de respeito ao interesse comum dos sócios; no segundo, descobre-se o complemento da "decisão contrária ao interesse social”, também utilizada para abuso da maioria. Aqui, porém, a contrariedade ao interesse social apresenta-se de forma viciosa: a atitude de opor-se seria contrária ao interesse social no caso em que ela impede a realização de operação essencial”. (ADAMEK, 2010, p. 60/61).
}

Do trecho da decisão acima, se fez necessária a distinção entre uma forma e outra de abuso, entre maioria e minoria, que segundo Adamek (2010, p. 60) “o abuso de maioria não se limita às operações essenciais”, o que equivale a dizer, portanto, que há uma amplitude onde as condutas abusivas por parte da maioria podem ser perpetradas.

Por outro, nas palavras de Adamek (2010, p. 61) “O abuso de minoria, pelo que foi decidido, não se referiria senão a operação essencial; em consequência é a conclusão lógica a extrair-se, opor-se a operação não-essencial não contrariaria o interesse social". É o que se extrai do caso francês, o fato da Madame Six, se opor a alteração contratual, de transformação para Sociedade Anônima, não se revelou como operação essencial, razão pela qual a Corte de Cassação cassar a primeira decisão que havia reconhecido o suposto abuso de minoria.

Para esclarecer a expressão: operação essencial, Adamek (2010, p. 61), expõe que ao elaborar o "conceito de abuso de minoria, a Corte de Cassação colocou, como elemento constitutivo, a atitude do sócio de impedir a realização de operação essencial". Que veio a ser definido "pouco tempo depois, a Corte de Cassação voltou a se manifestar e, em julgado de 09.03.1993, que se tornou bastante conhecido (Arrêt Flandin), reiterou 
a mesma definição de abuso de minoria anteriormente utilizada e, com isso, aportou novos subsídios à matéria”. (ADAMEK, 2010, p. 61)

Na causa em questão, os fatos controvertidos eram os seguintes. A sociedade limitada "Alarme Service Eletronic" compunha-se de quatro sócios e o seu capital social era de 20.400 francos. Com o advento da lei 01.03.1984, colocouse a necessidade de adequar o capital social ao novo piso mínimo estipulado. A administração social propôs, assim, no ano de 1985, o aumento do capital para o mínimo legal de 50.000 francos.

Porém, dois sócios, que em conjunto detinham mais de um quarto do capital social, impediram o aumento necessário. Em 1988, a administração social propôs novo aumento do capital, já então para 500.000 francos, muito além do mínimo estabelecido por lei.

Até aqui aproxima-se do caso da Madame Six, vez que se trata de ausência a fim de frustrar a aprovação da matéria. O comportamento de retardar a apreciação da deliberação societária, gerou medida judicial contra os recalcitrantes. E mais uma vez, a decidiu a Corte de Apelação de Paris que teria havido abuso de minoria, pois:

O aumento do capital solicitado à altura de 500.000 francos justificar-se-ia pelos documentos produzidos e o silêncio e a ausência do casal Flandin às assembleias extraordinárias, bloqueando com isso, de maneira injustificada, uma decisão necessária, decorreria do seu sistemático desejo de lesar os majoritários e, por efeito, o interesse social. (ADAMEK, 2010, p. 62).

Surgiu daí o recurso para a Corte de Cassação francesa, que, em 09.03.1993:

(i) Aprovou o julgamento dos juízes da instância ordinária na parte em que os julgadores "consideraram a bom direito que os Flandin cometeram abuso de minoria ao oporem-se ao aumento do capital para o montante de 50.000 francos, que era legalmente exigido e que era necessário à sobrevida da sociedade". Mas, no mesmo julgado,

(ii) Rejeitou o arresto recorrido, o qual, em suas razões de decidir, não teria indicado no que o aumento do capital para 500.000 francos seria "essencial" para a sociedade: Consequentemente, o aresto de origem foi cassado, sob o seguinte fundamento:

Considerando que, em se posicionando por tais motivos, impróprios a estabelecer no que a atitude dos Flandin foi contrária ao interesse geral da sociedade e no que teria impedido a realização de uma operação essencial para esta, e no único desejo de favorecer seus próprios interesses em detrimento do conjunto dos sócios, e (considerando) que ele (aresto recorrido) reputa ainda que os resultados da sociedade eram bons e que ela era próspera, a Corte de Apelação não deu base legal à sua decisão".

A Corte de Cassação, por este julgado, considerou que "essencial" seria: $\left(1^{\circ}\right)$ "legalmente requerida" e $\left(2^{\circ}\right)$ "necessária à sobrevida da sociedade". 
Veja-se, contudo, que a cada julgamento referente ao abuso de minoria, surge um novo critério subjetivo, no caso em tela, se entendeu por operação essencial aquela “necessária à sobrevida da sociedade”. (ADAMEK, 2010, p. 63).

Bom, se a expressão "operação essencial" não ficou imune a críticas, tampouco ficaria a nomenclatura "interesse social", surge-se, a dificuldade também de definir objetivamente o que é e quando se caracterizaria um comportamento contrário a tal interesse.

O autor, Adamek, neste particular, optou em abordar as dificuldades práticas na sua aplicação, dificuldades essas que, no direito francês, podem ser ilustradas pela análise de um controvertido aresto da Corte de Cassação, de 16.07.1998. No caso em questão, a discussão envolvia novamente a ocorrência de abuso de igualdade.

Nele, uma sociedade limitada composta por dois sócios igualitários vinha repetidamente destinados todos os seus lucros para a constituição de reservas, desde a sua constituição em 1973. Em dado momento, um dos sócios decidiu opor-se ao prosseguimento desta política e, por fim, exigiu o pagamento aos sócios dos dividendos dos exercícios de 1986 a 1989.

Parece que o verbo causador do problema/litigio é: opor-se a uma prática/cultura já fixada em determinada sociedade. O fato exigiu a apreciação da Corte, a qual sendo instada a manifestar-se sobre o litígio, a Corte de Apelação de Lyon, em 16.12.1996, negou-lhe os pedidos, ressaltando que a oposição do demandante em votar as deliberações no sentido de destinar à reserva os lucros dos quatro citados exercícios teria sido abusiva.

O recurso daí apresentado foi rejeitado pela Corte de Cassação, pelos fundamentos expostos no seguinte considerando do aresto:

Considerando, mais, que foi destacado, por motivos próprios e adotados, que a sociedade ELC tem necessidades de autofinanciamento mais ampla para investimentos e capital de giro, pelo fato de existir um desencaixe entre o financiamento exigido para a produção de seus produtos e o recebimento do preço de suas vendas, o aresto de origem reputou que esses fundos seriam extirpados se, como pretendia o Sr. Gilbert Curri, a totalidade do resultado contábil fosse distribuída sob a forma de dividendos e, além disso, que uma tal distribuição diminuiria o crédito da sociedade junto aos bancos, dado que a duração do litígio entre os sócios impediu a aplicação dos lucros e que, no presente, ela deve proceder à reabilitação de sua produção industrial por um custo o qual, malgrado o montante expressivo de seus próprios fundos, será, pelos próximos trinta anos, consumido pelo empréstimo realizado; que, diante de tais constatações, justifica-se a apreciação segundo a qual as exigências do Sr. Gilbert Curri respondem a um interesse egoístico e eram contrárias ao interesse da sociedade e que, ao impedir toda decisão da assembleia geral e criar obstáculos, cometeu um abuso no seu direito de voto, razão pela qual a Corde de Apelação podia, sem incorrer em nenhum vício, julgar como o fez. 
Para destacar os problemas das análises de casos práticos, Adamek (2010, p. 69), se vale das palavras de Dominique Schmidt, a pontua três questões:

\begin{abstract}
Em primeiro lugar, anotou que o caso versava sobre litígio entre sócios a respeito da distribuição de lucros e a sua destinação para a constituição de reservas. Não se tratava, pois, de operação essencial necessária à sobrevida da sociedade, e assim parece também ter entendido a Corte de Cassação. Isto porque, no recurso apresentado contra a decisão da Corte de Apelação, o recorrente objetou que o tribunal de origem não deu base legal à sua decisão de qualificar de abusiva a oposição de Gilbert Curri, pois deixou de esclarecer no que dita oposição teria impedido a realização de "operação especial"; decidindo-o, a Corte de Cassação deixou de refutar a imputação e o seu silêncio sinaliza, como assim deve-se entender, que o campo de aplicação da oposição abusiva não se circunscreve às operações essenciais necessárias à sobrevida da sociedade e se estende, pois, a todas as operações.
\end{abstract}

Na primeira abordagem, se verifica haver não mais uma discussão a respeito do que seria operação essencial necessária à sobrevida da sociedade, mas agora, tal conceito é extensivo a todas as operações.

Em segundo lugar, prossegue Dominique Schmidt, a fundamentação adotada pela Corde de Apelação e aprovada pela Corte de Cassação não merece aplauso. A Corte de Apelação estima que o interesse social orienta a constituição de reserva; ela deduz que a oposição à constituição de reservas teria sido contrária ao interesse social e fundada em motivo egoístico; (ADAMEK, 2010, p. 69)

O referido motivo egoístico se torna um problema, na medida em que a sua configuração em momento algum fora tratado e/ou perquirido se o comportamento, mesmo que contrário ao interesse social, ou a fim de frustrar operação essencial, seria atribuído o adjetivo de egoístico. Ou seja, o que vem a ser entendido por motivo egoístico? De qualquer forma, ela (Corte) então conclui, em julgamento aprovado pela Corte de Cassação, que referida oposição teria sido abusiva.

Observa-se, assim, que o aresto não caracteriza em nada a segunda condição necessária à qualificação do abuso, a saber, “o único desejo de favorecer os seus próprios interesses em detrimento do conjunto de sócios". Ela infere, segundo este aresto, que a oposição abusiva é aquela contrária ao interesse social, sem que seja necessário constatar o "único desejo". Não se pode, porém, aprovar esse método e a conclusão que ele induz. (2010, p. 70) 
Em terceiro lugar: a invocação do "interesse egoísta" suscita interrogações. O interesse do oponente foi qualificado de egoísta porque ele aparenta ser contrário ao interesse social (arbitrariamente) definido pelo juiz. A conjunção aditiva, ligando, no considerando precitado, o mote "interesses egoístas" ao mote "contrário ao interesse social", induz à oposição entre interesse individual e aquele da sociedade.

A conclusão que se extrai assim: a oposição do demandante, porque animada por interesse egoísta, eis que contrário ao interesse social judiciariamente definido, é abusiva, razão pela qual sua ação tendente à distribuição de dividendos não pode ser acolhida.

As três considerações afastam os falsos pressupostos jurisprudenciais para a caracterização do abuso de minoria, resta apenas a noção de interesse comum. (2010, p. 73).

Veja-se que da crítica três, que a construção do que venha a ser interesse egoísta é meramente interpretação subjetiva do juiz. Em nenhum outro lugar e/ou até mesmo precedente é invocado para dar a liberalidade ao órgão julgador de interpretar a situação e defini-la como: interesse egoísta, sobretudo para definir o destino de uma sociedade empresária.

Os exemplos são claros ao expor que a cada julgamento, a margem de subjetividade se expande de modo a deixar a relação societária e seus atos particulares cada vez mais inseguros, vez que ficam à mercê do subjetivismo do julgador.

De modo resumido, na França os tribunais passaram a observar toda a crídica doutrinária a respeito do tema, e conforme citado por Adamek, segundo informa Philippe Merle:

\begin{abstract}
A partir de 2006, a Corte de cassação não faz mais referência ao interesse social: para que haja abuso de minoria, é suficiente estabelecer de que modo a oposição é ditada pelo único desejo de favorecer seus próprios interesses de minoritário em detrimento do conjunto dos outros sócios:

Considerando que, para fixar a existência de um abuso de minoria ao encontro de $\mathrm{Y}$, o aresto se limitou a salientar que sua vontade de entravar o funcionamento da sociedade, ao interditar a realização de uma operação essencial para aquela, constitui um abuso de minoria; considerando que, ao assim decidir, sem caracterizar de que moto $\mathrm{Y}$ teve por único desejo favorecer seus próprios interesses em detrimento de outro associado, a corte de apelação não deu base legal à sua decisão, a mesma é cassada".
\end{abstract}

A construção jurisprudencial francesa, a cada julgado, permitiu verificar a complexidade de se analisar e configurar os excessos praticados pelos sócios a fim de caracterizá-los como abuso de minoria e/ou maioria. Adamek apresenta o que se entende sobre a matéria atualmente, com base nas palavras de Dominique Schmidt, que sintetiza que: 
$\left(1^{\circ}\right)$ o abuso (de minoria, de maioria ou de igualdade, pouco importa) não radica na defesa de direitos e interesses ex causa societatis, mas na busca de um interesse outro diverso daquele de sócio, ou seja, na busca da satisfação de interesse extrassocietário em contraste com o interesse comum dos sócios ou, o que dá no mesmo, pelo desejo de satisfazer um interesse próprio em ofensa às legítimas expectativas dos demais sócios, as quais têm no fim social a sua justificativa.

$\left(2^{\circ}\right)$ o abuso de minoria descende da mesma lógica do abuso de maioria, pois ambas resultam de uma situação de conflito de interesses e se caracterizam pela busca de vantagem particular em detrimento do interesse comum dos sócios; e

$\left(3^{\circ}\right)$ a noção de interesse social e as tentativas de enquadrá-lo no âmbito de operações essenciais necessárias à sobrevida da sociedade apenas turvam o conceito de abuso de minoria, favorecendo, consequentemente, a propagação de comportamentos desleais. (ADAMEK, 2010, p. 78).

Fica, portanto, excluída a expressão “interesse social”, que outrora, naquele país, servia de parâmetro para a configuração do abuso de minoria. O que fica de lição, ao olhar para trás, é que a cada julgado, a complexidade se ampliava até se chegar a condição de definir critérios mais objetivos capazes de mitigar o subjetivismo do julgador.

\subsubsection{A experiência alemã.}

Diferentemente do que ocorreu na França, em que a teoria do abuso de minoria focou e se desenvolveu em torno do conceito de interesse social (e interesse comum), é, atualmente, na Alemanha que o tema, no que diz respeito ao direito societário, ganha maior relevo.

A temática sobre abuso de minoria em direito societário, na Alemanha, conforme ressalta Adamek (2010, p. 79):

Em comparação ao nosso sistema de direito societário - que, inicialmente, encontrou nos direitos europeus dos países de língua latina a sua fonte mais próxima de inspiração (França, Portugal e Itália, cronologicamente) -, o moderno direito societário alemão distingue-se de todos os demais, por nele restarem os diversos institutos solidamente estruturados sobre os conceitos fundamentais (e funcionais!) de fim social (ou fim comum) e dever de lealdade.

Então, nesse particular, a análise se debruça em relação às expressões "fim social" e “dever de lealdade", está última que nas palavras de Verçosa (2014, p. 126), pode ser entendido que o "dever de lealdade, portanto, estabelece-se entre o sócio e a sociedade e transparecerá no momento em que o sócio, nesta qualidade, p. ex. estiver exercendo o direito de voto". 
Ora, na perspectiva acima, o dever de lealdade se coloca em evidência assim que testado via votação em prol de interesses da sociedade, é isso que se depreende quando Verçosa (2014, p. 126) afirma que: "Neste caso, o voto não poderá ser manifestado de forma abusiva, nem em condição de conflito de interesses". A doutrina, nesse particular, pelo menos segundo Verçosa, volta a resgatar a expressão afastada pela jurisprudência francesa: conflito de interesse, vez que se para os franceses, o que ficou de fora da análise do que é abuso de minoria, é a expressão: interesse social, o conflito de interesse é justamente a manifestação de vontade colidentes entre a figura do sócio e a figura da pessoa jurídica.

Não por outra razão, Verçosa (2014, p. 126), conceitua a abusividade no voto, sendo aquela que "O voto abusivo é aquele proferido contra o interesse da sociedade, vinculado à realização do objeto social, que é o campo de sua atividade. (...) o conflito de interesses quanto à pessoa do sócio irá manifestar-se também por meio do voto".

Adamek (2010, p. 80) esclarece:

\begin{abstract}
Em sentido amplo, o fim social abrange o escopo-meio (ou objeto) e o escopofim (objetivo): escopo-meio ou objeto (empresa, no caso da sociedade empresária) é a atividade à qual a organização societária se dedica; e escopofim ou finalidade é, para as sociedades, a sua finalidade lucrativa: a produção e partilha dos resultados da atividade social entre os seus membros.
\end{abstract}

Depreende-se que essa característica acima, possui uma natureza hibrida no sentido amplo, o que Adamek (2010, p. 80) as equiparou "ao sinalagma nos contratos bilaterais -, a doutrina atribui-lhe eficácia constitutiva e eficácia funcional", sendo que a distinção entre uma e outra encontra-se:

Tem eficácia constitutiva, na medida em que o fim comum é elemento constitutivo das organizações societárias: não há sociedade ou associação sem fim comum próprio, que não se confunde com o fim individual porventura perseguido pelos seus integrantes (e o qual não conflita nem exclui aquele fim comum). (...) Como registra Werner Flume, "o fim comum societário não é, em realidade, nem o fim próprio nem fim alheio, mas fim comum supraindividual: é o fim da sociedade como sociedade de pessoas". (2010, p. 81).

A constituição da sociedade empresária se faz mediante um plano pretérito de persecução do resultado que se objetiva alcançar com ela, assim, Adamek (2010, p. 82), ressalta que "no plano constitutivo, o fim social representa a causa do contrato de sociedade". Ou seja, não haveria razão para a sua constituição se não houvesse um 
objetivo e finalidade para com ela ser atingida. Segue Adamek (2010, p. 82), afirmando que a expressão [fim comum] "define o interesse social, pois esse nada mais é, em sentido estrito e técnico, do que o interesse comum dos sócios à realização do escopo comum, por via de consequência, é também o fim comum que bitola os conflitos de interesse em sentido próprio (LSA, art. $115^{4}$, e CC, art. $\left.1.010^{5}, \S 3^{\circ}\right)$ ”".

Por fim, Adamek (2010, p. 83), ainda apresenta como como elemento constitutivo, o fim social, também é "dotado de eficácia funcional, pois: (i) fixa as diretrizes da política social; (ii) determina os direitos e deveres dos sócios (em especial a sua intensidade), delimitando, assim, as esferas individual e coletiva; e (iii) dirige os estágios da vida social".

Dessa exposição é compreensivo que a sociedade empresária apresenta uma múltipla relação, "entre os sócios e entre estes e a sociedade" e essa fusão de relações e interesses é marcada pela finalidade comum.

\section{ABUSO DE MINORIA NO DIREITO BRASILEIRO.}

Nesse tópico é onde reside a atenção do presente artigo, vez que até aqui o que se fez foi evidenciar a construção do tema em direito comparado, modelo francês e alemão, resta, portanto, apresentar a forma pela qual o Direito brasileiro encara e desenvolve a temática do abuso de minoria em direito societário, até porque é muito tímida a abordagem e com muita carga de subjetividade dos órgãos julgadores.

A propósito, nas palavras de Adamek, (2010, p. 116), enfatiza que "a doutrina ainda não enfrentou de maneira específica, (...) na jurisprudência, as referências existentes são de mera adjetivação da conduta dos sócios". Leia-se, adjetivação como subjetivismo e achismo, não se revelam como decisões baseadas em critérios fixos onde as partes previamente poderiam ter a chance de escolher ou não adotar determinada atitude no caso concreto.

\footnotetext{
${ }^{4}$ Art. 115. O acionista deve exercer o direito a voto no interesse da companhia; considerar-se-á abusivo o voto exercido com o fim de causar dano à companhia ou a outros acionistas, ou de obter, para si ou para outrem, vantagem a que não faz jus e de que resulte, ou possa resultar, prejuízo para a companhia ou para outros acionistas.

5 Art. 1.010. Quando, por lei ou pelo contrato social, competir aos sócios decidir sobre os negócios da sociedade, as deliberações serão tomadas por maioria de votos, contados segundo o valor das quotas de cada um.

§ 3o Responde por perdas e danos o sócio que, tendo em alguma operação interesse contrário ao da sociedade, participar da deliberação que a aprove graças a seu voto.
} 
Em outras palavras, se pelo menos a jurisprudência brasileira estivesse consolidada, com bons parâmetros definindo o que caracteriza abuso de minoria, (p.ex.), a ausência de legislação seria de menor relevância, embora, talvez não fosse o ideal considerando a cultura jurídica que se comporta a depender da lei e, nem sempre da norma.

De modo resumido, a falta de atenção ao direito de minoria (antes da obra de Adamek), e até mesmo, após ela, não significa que não tenha gerado problemas práticos de difícil resolução, sobretudo pela (in)compreensão e falta de delimitação conceitual do que é e quando ocorre o abuso de minoria em direito societário.

\subsection{A (IN)COMPREENSÃO DO CONCEITO DE MINORIA EM DIREITO SOCIETÁRIO E A JURISPRUDÊNCIA}

A falta de parametrização e delimitação clara do ato que possa configurar, por si só, abuso de minoria, gera a incompreensão do termo. Nas palavras de Adamek (2010, 143), "a teoria do abuso de direito - que costuma ser intuitivamente invocada, diante da parcial correspondência das expressões - não se mostra apta a regular, e maneira completa, as situações características de abuso de minora em direito societário".

Veja-se que a partir da construção jurisprudencial em nível internacional - a experiência francesa e alemã - já servem de referencial para verificar que a prática demandas judiciais sobre o tema - são de complexidade impar na medida em que, talvez, seja somente diante do caso concreto que se possa dizer se é ou não caso de abuso de minoria em direito societário.

Nesse sentido, o julgado abaixo aponta que em ação anulatória em que pretendia a autora, ora apelante anulação de deliberação societária e posterior atos dela originados, em primeiro grau teve sua pretensão julgada improcedente com o argumento de que "houve abuso do direito de minoria da autora ao não endossar a proposta de aumento de capital social, aprovada em assembleia".

No particular caso, o juízo a quo partiu do pressuposto de que a resistência/oposição da parte minoritária, por si só, já bastaria para configurar o abuso de minoria, pelo simples fato de não endossar a proposta de aumento de capital social, mesmo que aprovada em assembleia. Ora, aqui é flagrante que além de julgamento alheio às provas dos autos, ainda houve nítida confusão e/ou dificuldade de enquadrar a 
aplicação/configuração da teoria do abuso de minoria, razão pela qual, em grau recursal, a decisão fora reformada.

CIVIL. APELAÇÃO CÍVEL. AÇÃO ANULATÓRIA. PRELIMINAR. NULIDADE DA SENTENÇA POR AUSÊNCIA DE FUNDAMENTAÇÃO. NÃO CONFIGURAÇÃO. MÉRITO. NULIDADE DE DELIBERAÇÃO DE SOCIEDADE LIMITADA. TEORIA DE ABUSO DO DIREITO DE MINORIA. NÃO APLICAÇÃO. AUTORIZAÇÃO JUDICIAL PARA DISPOR DE BENS DE CURATELADO E INTERDITADO. NECESSIDADE. ANULAÇÃO DA VOTAÇÃO ASSEMBLEAR. INVERSÃO DOS ÔNUS DA SUCUMBÊNCIA.

É nesse sentido que, no "mérito, a existência de cláusula expressa no contrato social que condiciona a majoração do capital social à aprovação unânime dos sócios. Regramento legal que exige a mesma proporção, ou seja 100\% dos sócios (art. 999 c/c 997, do CC, aplicáveis por força do artigo 1.053 do CC)". Assim, a oposição da autora/apelante não se trata de mera resistência pela resistência, mas sim de ato legítimo, portanto, "inexistência, no caso, de abuso do direito de voto". E diante do exposto, decidiu o Des. Cesar Loyola, que:

\begin{abstract}
A deliberação para majoração e forma de integralização do capital social, por configurar ato extraordinário de gestão estrutural da sociedade, extrapola os limites das atribuições conferidas ao curador e inventariante, exigindo-se, em ambas as situações, a obtenção da devida autorização judicial, sob pena de nulidade da deliberação societária que verse sobre os citados temas (art. 166 do Código Civil). 5.O provimento do apelo implica na inversão dos ônus da sucumbência e arbitramento dos honorários com a majoração recursal. 6.Apelação conhecida e provida. (TJDF, 20140110855747APC (002021015.2014.8.07.0001)
\end{abstract}

Do caso acima, não é apenas o problema da análise do caso concreto em si somente que dificulta na configuração da teoria do abuso de minoria, mas também a decisão precipitada em não verificar as provas produzidas nos autos da maneira adequada. De qualquer forma, está-se diante de invocação da Teoria do Abuso de Minoria, mesmo que de forma equivocada.

Ora, como mencionado no início do artigo, ao se falar em abuso de minoria, comparativamente está a se falar em abuso de maioria e/ou até mesmo de abuso de poder de controle, o que também pode gerar certa dificuldade em configurá-lo, ou até mesmo, interpretar no caso concreto que não se está diante de abuso de maioria e/ou abuso de poder de controle, mas sim de abuso de minoria em não se sujeitar e aceitar as decisões majoritárias por mero interesse de se opor.

É o que se verifica no julgado abaixo. 
PODER DE CONTROLE. NÃO OCORRÊNCIA. 1. Recurso especial interposto contra acórdão publicado na vigência do Código de Processo Civil de 1973 (Enunciados Administrativos nos 2 e 3/STJ). 2. Ação proposta sob a alegação de que a sociedade controladora agiu com abuso do poder de controle, a resultar na diluição injustificada da participação dos acionistas minoritários no capital social da sociedade controlada e na redução do valor patrimonial de suas ações. 3. A atuação em juízo do acionista minoritário, na específica hipótese do art. 246, $\S 1^{\circ}$, "b", da Lei $n^{\circ}$ 6.404/1976, restringe-se a atos praticados pela sociedade controladora com infração ao disposto nos arts. 116 e 117 do mesmo diploma legal. 4. Age com abuso do poder de controle a sociedade que orienta a atuação dos administradores para fim estranho ao objeto social, com desvio de poder ou em conflito com os interesses da companhia. 5. Hipótese em que o ato de aquisição do controle acionário de outra instituição bancária, a despeito do elevado valor do seu passivo a descoberto, mostrou-se perfeitamente alinhado ao objeto social da sociedade controlada. Necessidade de expansão da atividade empresarial, com aumento da sua participação no mercado financeiro nacional. 6. De acordo com a autonomia da decisão empresarial, não compete ao Poder Judiciário adentrar o mérito das decisões tomadas pelo acionista controlador na condução dos negócios sociais, ressalvada a hipótese de abuso do poder de controle, não verificada na espécie. 7. Havendo razões de ordem econômica ou administrativa para a proposta de aumento de capital social, sobretudo quando tal medida é indispensável à própria sobrevivência da empresa, considera-se justificada a diluição da participação dos sócios minoritários, aos quais deve ser assegurado o direito de preferência na aquisição das novas ações, nos termos do art. $170, \S 1^{\circ}$, da Lei $n^{\circ} 6.404 / 1976$. 8. Recurso especial não provido. RECURSO ESPECIAL No 1.337.265 - SP (2012/0161659-3) Rel. Min. Ricardo Villas Bôas Cueva.

Depreende-se do julgado acima que a configuração do exercício abusivo minoritário ou majoritário - é uma questão em que o caso concreto apresentará indícios e provas do pode ou não configurar o abuso. O que, segundo Adamek (2010, p. 143), "a repressão ao abuso de direito, em realidade, nada mais é do que uma decorrência básica da boa-fé objetiva, até porque, segunda frisava Antônio Junqueira de Azevedo, o abuso de direito é sempre uma quebra da boa-fé no seu nível mais elementar”.

Com isso, um requisito que já serve de parâmetro para se analisar se há (houve) abuso de direito (maioria ou minoria), é a presença da boa-fé objetiva no ato que se praticou e visa impugná-lo, isso porque aquela mesma presumida boa-fé que foi manifestada em querer ingressar na sociedade empresária, deve se manter durante a consecução do contrato que as vincula, bem como, inclusive no ato de, se for o caso, oporse.

\section{CONSIDERAÇÕES}

Nas linhas introdutórias aqui lançadas sobre a dificuldade de configurar o abuso de minoria e, consequentemente repelir em direito societário, fica evidenciado na medida 
em que se examina decisões e da construção jurisprudencial em âmbito nacional e internacional, ainda há margem para muito estudo e, quem sabe, se aprofundar na análise do tema a fim de construí critérios mais objetivos capaz de facilitar a compreensão da Teoria do Abuso de Minoria e torná-la de melhor aplicação sem discrepâncias e/ou sem a dependência do subjetivismo do órgão julgador.

\section{REFERÊNCIA}

BRASIL - Tribunal de Justiça do Distrito Federal - (TJDF, 20140110855747APC (0020210-15.2014.8.07.0001)

- Superior Tribunal de Justiça - STJ - RECURSO ESPECIAL No 1.337 .265 SP (2012/0161659-3)

GUARAGNI, Fábio André; KOBUS, Renata Carvalho. O ABUSO DO PODER SOB O ENFOQUE DO DIREITO PENAL ECONÔMICO. Revista Juridica, [S.1.], v. 2, n. 43, p. 234 - 259, fev. 2017. ISSN 2316-753X. Disponível em: <http://revista.unicuritiba.edu.br/index.php/RevJur/article/view/1830/1205>. Acesso em: 19 abr. 2020. doi:http://dx.doi.org/10.21902/revistajur.2316-753X.v2i43.1830.

NERY JR. Nelson. Abuso dos direitos de sócio minoritário - abuso do direito de demandar. In: Soluções práticas de direito: direito do consumidor, direito falimentar e direito societário, 2 ed. São Paulo: RT, 2014).

SALAMA, Bruno M. Entendimento jurisprudencial sobre o poder da maioria nas decisões empresariais; in: Fundamentos econômicos do Direito de Empresa. Coord. Paula A. Forgioni ... [et al.]. Curitiba: Juruá, 2019)

VON ADAMEK, Marcelo Vieira. Abuso de minoria em direito societário. 1. ed. São Paulo: Malheiros Editores, 2014. 